\title{
Young Long-term Unemployed and the Individualization of Responsibility
}

\section{Jennifer Hobbins'}

Work Life Sciences, Karlstad University, and Department of Leadership, Swedish Defence University, Sweden

\begin{abstract}
In Sweden, as in most Western societies, a common belief is that unemployment is somehow linked to the individual, her lack of work ethic, or other personal shortcomings rather than to structural causes. This is not only manifested in public arenas such as the media or political debates but also in our social surroundings. In recent years, these views have gained importance, indicating a shift in the location of responsibilities from the welfare state to the individual. This shift entails high demands and expectations on unemployed people and is something they have to deal with and relate to. One of the most exposed groups is young long-term unemployed.

The aim of this article is to highlight how the discourse of individualized responsibility is reflected in unemployed peoples' stories, and to shed light on the ways in which young long-term unemployed adults relate to and position themselves toward this discourse. Based on 18 qualitative interviews with young Swedish long-term unemployed people, the findings show three approaches to the discourse: conformity, distancing, and resistance.
\end{abstract}

\section{KEY WORDS}

Long-term unemployment / individual perspective / discourse / positioning / qualitative / responsibilities / young adults

DOI

10.19154/njwls.v6i2.4971

\section{Introduction}

he significance of work and work ethics is to be found in political debates and the media, and not least during social interaction. This is interlinked with the sociomoral principle of 'doing your bit' (Johansson \& Møller, 2009, p. 14). Doing your bit not only means sharing society's workload but also being responsible for your own keep.

Conceptions of unemployment in terms of being due to the attitude of the unemployed toward work, or their personal attributes, are well established in society (Gallie, 1994; Andersson, 2003; Van Oorschot, 2006). This is a discourse deeply rooted in history, but it is one which, during recent years, has gained reinforced significance, both in political contexts and in social ones. Swedish social and labor market policy has changed over the last two decades toward an emphasis on activation. This implies an increased emphasis not only on active job-seeking, participating in active labor market

\footnotetext{
${ }^{1}$ Jennifer Hobbins, Swedish National Defence college, Dep of Security, Strategy and Leadership, SE - 651 80 Karlstad, jennifer.hobbins@fhs.se.
} 
measures and similar but also on unemployed individuals' personal responsibilities and obligations (Johansson \& Møller, 2009).

Taking center stage in this article is the conception that unemployment is linked to personal shortcomings. This notion has parallels with a more general societal trend toward individualization in terms of the individuals' moral and citizenly duties (e.g., Rose, 1999; Beck, 2000; Giddens, 2003; Gillberg, 2010; Allvin et al., 2011). These perceptions may influence unemployed people in different ways such as shaming experiences that, in turn, may lead to feeling dejected and mental ill-health (Starrin et al., 1999; Rantakeisu, 2002).

Taking center stage in this article is the conception that unemployment is linked to personal shortcomings. This notion has parallels with a more general societal trend toward individualization in terms of the individuals' moral and citizenly duties (e.g., Rose, 1999a; Beck, 2000; Giddens, 2003; Gillberg, 2010; Allvin et al., 2011). Unemployed people are surrounded by this discourse and repeatedly encounter it in various social contexts. Thus, it is reasonable to assume that these these perceptions may influence the unemployed in different ways such as shaming experiences that, in turn, may lead to feeling dejected and mental ill-health (Starrin et al., 1999; Rantakeisu, 2002). As a result, many unemployed people are very concerned with how they are assessed and valued by others, especially in connection with their encounters with other people, government agencies, and welfare institutions (Starrin et al., 1996). Thus, knowledge about how unemployed relate to the individualization of responsibility is of increasing importance.

The purpose of this article is twofold. First, it aims at highlighting and discussing the ways in which individualized responsibility for being unemployed are reflected in unemployed peoples' own stories. Second, it aims at analyzing how young unemployed relate to this discourse. The article thus focuses on displaying the individual perspective and individuals' interpretations of the discourse.

\section{The welfare state and views of unemployment}

How unemployed have been regarded has a long history with roots stretching back to the middle ages. In western societies, during the early middle ages, poverty was a natural part of society and one which gave rise to pity, but which later became shameful, as it was associated with moral deficiency (Salonen, 2009). In parallel with industrialism, the core of the moral shortcomings poor people were considered to be distinguished by were idleness in the form of unwillingness to work and a tendency to cadge on others' resources (cf. Andersson, 2003).

Economic theories have been characterized by similar conceptions. During the postwar period, modern Swedish social policy was formed mainly on the basis of social democratic ideas, strongly influenced by the Keynesian view of unemployment as a macroeconomic problem with a little demand for labor. This interpretation has gradually had to give way to liberal economic influences and a different view of the problem of unemployment: here, it is regarded as a microeconomic problem due to an overly rigid legislation on employment protection, minimum wages that are too high, and an unreasonably generous level of unemployment benefit (Morel et al., 2012). When it comes to views of the individual, the ideal of most western countries has evolved toward an independent, responsible, and active individual. This ideal has been ideologically influenced by the European Union (the EU) and the Organisation for Economic Co-operation and 
Development (the OECD), and is characterized by a growing individualization of risks that were previously the responsibility of the welfare state. One example of such risks is unemployment (Crespo \& Serrano Pascual, 2004).

Ever since the 1980s, the benefit levels paid to the unemployed have been hotly debated in the public domain, both in Europe and in the rest of the Anglo-Saxon world. Advocates of minimal welfare programs argue that general welfare programs are counterproductive since leading to increased passivity in benefits recipients, something which risks leading to so-called welfare dependency. According to this reasoning, welfare dependency should be counteracted by a more pronounced conditionalization of social entitlements (Mead, 1986; Government Bill, 2010/2011:1, p. 34). Inspired by US welfare reforms during the 1990s and 2000s, most of Europe's democracies have formed their social policies on the basis of these principles. Despite ideological departure points differing from country to country, the conditionalizing of social entitlements has increased in all western European democracies. Although these reforms are adapted to the countries' own traditions and institutions, contractualization in order to gain access to welfare has become a key element. The increased conditionalization of social entitlements is a part of the trend toward activation, something that has been compared with 'workfare' in the US (Handler, 2003) and that has come into focus during the current debate on labor market and social policy. In Sweden's welfare system, too, the main focus on the significance of the work ethic has increased during recent years (Johansson \& Møller, 2009).

As in the majority of European countries, Swedish youth unemployment rates have been rising since the 1990s. Today's young adults are thus acquainted with a serious labor market situation, especially regarding their own age group. It is reasonable to assume that this could contribute toward the normalization of our views of young people who are out of work. At the same time, unemployment at a young age is assumed to lead to passivity and an inadequate level of motivation to find work, and further, that these consequences may be consolidated and lead to permanent social exclusion. In several European countries, such as Sweden and Germany, this assumption permeates the labor market legislation surrounding young and unemployed persons up to the age of 25 (see Grimmer \& Hobbins, 2014). Thus, this is an example of how a discourse is materialized as an individual problem in state institutions and policy instruments such as legislation and rules and regulations (Junestav, 2009; see also Ostrom, 2005).

\section{Discourse, individualization, and attitudes toward unemployment}

Discourses can be described as a system of statements about a certain topic. These statements are interpretations of our social reality; understandings that contain a power dimension and that structures our knowledge about the social world. This reality is, in part, constructed by the production and institutionalization of spoken and written statements, and reproduced by individuals who have internalized this knowledge. Internalization of societal values and discourses is part of the human socialization process. Thus, the reproduction of discourse can be both conscious and unconscious since people internalize societal norms and ideals and make them their own (Berger \& Luckmann, 1967). Also, social identities, how we regard ourselves, and how we believe others regard us, and social relations are part of our reality. In the processes of interaction, not only a 
significant part of the social and cultural reproduction takes place but also moves of change (see Winter Jørgensen \& Phillips, 2000).

The following examples regarding discourses of unemployment may illustrate the role of social interaction: it may include media articles on the unwillingness of the unemployed to work despite the number of unfilled vacancies and threats of sanctions, the feeling of humiliation during encounters with the Public Employment Services (which in the following will be referred to as the PES) or a potential employer, or well-intentioned questions from acquaintances asking if a person has managed to find a job yet. Here, asymmetrical power relations that give individuals both the blame and the responsibility for their unemployment are reproduced.

By adopting a stance on a discourse, people position themselves in relation to it. In other words, positioning means individuals making use of various discourses to describe and relate to reality. Various understandings of our social reality can support the dominant discourse. They can also underscore other values and, in so doing, compete with it, or question and criticize the dominant description of reality in the form of counter discourses (ibid, 2014). By using various discourses, people take a stance on where they are in relation to the dominant discourse. This 'negotiation' can be interactive, meaning that what one person says positions another (Davies \& Harré, 1990). With regard to unemployment and activation policy, individualization thus is a key concept. In this article, I refer to this trend as the discourse of the individualization of responsibility. The discourse is analytically relevant, as it is a dominant logic within society. This means that it is not only institutionally rooted in, among other things, legislation, welfare systems, and social structures, but also in people using the discourse and thus making it valid (Dahl, 2014).

How people reflect on, negotiate, and relate to discourses of unemployment is interesting due to the fact that the awareness of discourses surrounding unemployment has increased as a result of public discussions about activation policies, a concept that is intimately linked to the notion of individualization. The individualization of living conditions is a general societal trend that has emerged during the past decades. This concept is interpreted and used in different ways in different contexts. Both focus and effects of this trend are ambiguous. On the one hand, there is the notion of individual autonomy and increasing possibilities for people to shaping their own lives and choose new paths. On the other hand, the increasing importance of the individual also encloses expectations on the individual taking responsibilities that previously belonged to actors and units like the welfare state, the labor market, or the family. In this sense, the discourse has been institutionalized and, as a consequence, individual citizens are more exposed to social risks, and collective values are fragmentized (Sennett, 2000; Gillberg, 2010; Ulmestig, 2013). Thus, the notion of individualization may refer to both individual living patterns and preferences and the organizing of the labor market and the welfare society (see Valkenburg, 2007). In relation to social contexts and people's attitudes toward unemployment, individualization tendencies are related to beliefs that the cause of unemployment exists within the individual's lack of resources, for example, competence, capability, motivation, or work ethic (Van Oorschot, 2006).

The increased emphasis on the individual's attributes, responsibilities, and obligations forms the basis of the tightening up of the conditions enabling access to the Swedish unemployment insurance. From 2006 and on, a marked intensification of these conditions is discernible: the conditions for membership of an unemployment benefit 
fund and being entitled to unemployment benefit have become tougher, sanctions in the case of infringements of the rules governing unemployment benefit have increased and become differentiated, and the number of waiting days has increased while compensation levels have fallen (Swedish Federation of Unemployment Insurance Funds, 2008). Further, the political understanding and practices of the work strategy have changed. The work strategy is a guiding principle that has permeated Swedish labor market and social policies during the past centuries. Although its emphasis has varied, the core consists of work and each and one making their own living (Junestav, 2004). In addition to the emphasis on work, social democratic governments have traditionally underscored and invested in education and qualification as a tool to secure a highly skilled labor force. However, during the past decade, there has been a palpable shift in the understandings away from resting on two cornerstones, that is, work and competence, toward focusing more or less exclusively on work (Bengtsson \& Berglund, 2012; Morel et al., 2012). In the context of active labor market policies, the work strategy has also become a political instrument for effectivization and modernization of the labour market, partly by governing and controlling the unemployed (Johansson \& Møller, 2009).

When political messages are spread, via the media for example, they can have a major impact and affect people who take this description of reality on board and make it their own. A political message that blames and shames the individual for unemployment and other social problems coincides strikingly frequently with suspicious and negatively inclined public opinion (see Oschmianski, 2003). This becomes evident in empirical studies showing that the general attitude toward people who 'don't do their bit' has become increasingly hostile. The combined picture of European research is that the unemployed are thought of as unwilling to work and that they have dubious morals with regard to receiving government handouts. Further, the unemployed tend to be perceived as spineless, less persevering, and less reliable, and do not assume responsibility for themselves (Van Oorschot, 2006).

In Sweden, the picture is contradictory. A study by Furåker and Blomsterberg (2002) showed that almost $78 \%$ of the respondents believed that the unemployed could get a job if they wanted to. Studies of Swedish employers show that job-seekers with an experience of longer periods of unemployment are regarded as less productive or less reliable (Agell \& Lundborg, 1999; Calmfors et al., 2001). At the same time, research shows that the proportion of people who suspect that the unemployed are workshy constitutes about one-fifth, which means that four-fifths can be interpreted as less negatively or benevolently inclined toward the willingness to work shown by the unemployed (Svallfors, 2011). From the perspective of the unemployed, they perceive that people in general think that they are as lazy and unwilling to work, and cadging on society (Andersson, 2003).

Studies of people's attitudes toward unemployment show that they are influenced by several, partly interacting factors. Circumstances that seem to contribute to a more generous attitude vis-à-vis the unemployed primarily include periods of high unemployment, since unemployment can then to a lesser extent be ascribed to the individual's potential shortcomings, one's own ongoing unemployment, or the ages of those unemployed, where youth unemployment is often regarded as less shameful than adult unemployment (Furåker \& Blomsterberg, 2002; Gallie \& Paugam, 2002). This is assumed to be connected with the fact that youth unemployment is more widespread, which will lead to normalization (Furnham, 1982; Willis, 1986). Other factors contribute to 
explaining a more restrictive belief in both the willingness to work and honesty of the unemployed when it comes to societal support. Here, one of the most significant factors of influence seems to be a strong rooting in the Protestant work ethic, which, using an individualistic model of explanation, is of the opinion that the behavior of each citizen bears the responsibility for prosperity or poverty (Furnham, 1982). Another influential variable is a more conservative political orientation, involving a tendency to shame the unemployed for their situation, and associating them with negative attributes such as laziness (McFadyen, 1998).

These two standpoints, the more suspicious, accusatory and shaming on the one hand, and the more generous, loyal and understanding on the other hand, may appear to be each other's antithesis. However, both these extremes can be accommodated within the same person's moral repertoire, thus illustrating the complexity of people's attitudes toward welfare in general and toward the unemployed (Eardeley \& Matheson, 2000). This also demonstrates that, in addition to the dominant discourse of individualized responsibility, there are other discourses (Dahl, 2014).

Even though the unemployed have internalized and reproduce the discourse themselves, encounters with representatives of government agencies and welfare institutions, as well as family, friends, and acquaintances, can lead to shaming and stigmatizing experiences. When encountering her or his surroundings, the unemployed person is made aware of how other people see her or him and what she or he is unable to live up to. When individuals are reminded and made aware of deviating from prevailing societal norms, or have some other deficiency ascribed to them, they will have to adopt a stance on the discourse and position themselves in relation to their surroundings (Andersson, 2006).

\section{Methods and Data}

This article focuses on the individual perspective and on the reflexive patterns of young long-term unemployed adults in relation to the discourse of individualized responsibility. The findings of the article are based on qualitative interviews with people whose long-term unemployment has allowed them to gather a significant amount of experiences and reflections concerning unemployment. Data gathering was carried out in a mid-sized Swedish city and its environs between February and December 2010, within the framework of a European study of youth unemployment. The selection consists of 18 young adults, 6 women and 12 men aged between 20 and 34 years. The notion of young adults considers the period between youth and the entrance into adult life. This period has become prolonged since the establishment on the labor market occurs later, which may have implications for the establishment also on other areas associated with adult life, such as moving to one's own house, starting a family, and having children (e.g., Furlong, 2009; Gillberg, 2010). Thus, in order to capture not only the variation of experiences, living conditions, and prerequisites but also attitudes and reflections, the selection is inclusive and comprises individuals up to the age of 34 .

The interviewed young adults had, at the time of the study, been unemployed consecutively for at least 12 months. Their experiences of unemployment often include even longer consecutive periods of unemployment, in some cases sandwiched between briefer limited-duration employments or hourly-waged temping work. All the interviews lasted between 30 minutes and 2 hours, and were recorded and transcribed verbatim. 
The interviews were semi-structured, that is, they touched upon certain themes around which the respondents associated freely. The original study touched upon the following main themes: social and financial dimensions of unemployment, experiences regarding the Public Employment Services (the PES), politics, and political activities. During the interviews, which contained several broad thematic areas, two questions were asked directly concerning this article's purpose: whether or not the respondents had gained any negative experiences in connection with being unemployed and where they felt the reasons for their unemployment lay. References to thoughts about and encounters with other people's views of unemployment were, however, recurrent throughout the interviews in widely differing contexts.

The analytical process took place in two rounds. The first round, which was conducted within the framework of the project, started off with an inductive approach using a systematic analysis process (see Glaser \& Strauss, 1967; Miles \& Hubermann, 1994). Initially, a microanalysis was conducted using open coding, followed by categorization and comparison of the codes in order to identify categories and themes categorizing the data. During the second round, I returned to the data on the basis of my interest in the current purpose. After having reread the material and found new themes and categories, for example, responsibility, social interaction, and activity, I conducted a more selective coding of the remaining data, during which I searched in a more focused way for codes concerning both these and adjacent categories. Here, I was particularly interested in statements and expressions connected to unemployment and responsibility in order to investigate how the respondents relate to these concepts.

\section{Three approaches}

As we have seen, a dominant logic in Swedish society, as in the rest of the western World, is thus that a large part of the responsibility for being unemployed lies with the individual her- or himself. However, scholarly writings on how unemployed relate to this individualization of responsibility point in different directions. Still remaining unclear are thus the reflexive patters of unemployed young adults. The discourse was also a point of departure for parts of the interviews through questions about responsibility, as well as one's own and other people's attitudes towards unemployment, and thus permeated the conversations. The discourse on the individualization of responsibility thus forms the basis of my analysis, which focuses on how young unemployed people relate to it. The analysis resulted in three overarching approaches. The first entails conformity with this logic, the second deals with distancing from it, while the third position taken concerns resistance to it. The various approaches are not mutually exclusive categories, instead they are able to supplement and to some degree overlap each other.

\section{Conformity}

In the interviews, it was clear that the conception of unemployment in terms of being linked to the individual's behavior and shortcomings, and thus mainly being the individual's responsibility, is the dominant image. A discourse can only be dominant if it is used and if it constitutes a reference point. The discourse's dominance became evident during 
the interviews by means of recurrent references to this logic during different parts of the conversations, also outside the framework of the direct questions. The unemployed related to the discourse, confirming and recreating it without fundamentally questioning it (cf. Dahl, 2014). Conformity to the dominant discourse was prominent in two ways: partly through the unemployed emphasizing the activity, which is regarded as a laudable ideal within this discourse, and partly through the apportioning of blame.

Being active is a deeply rooted ideal, from the Protestant work ethic to the work strategy, especially when it comes to earning one's keep (Junestav, 2004; Salonen, 2009). This active ideal also permeates other areas, for example, societal commitment in the form of political participation, involvement in voluntary organizations, or the practicing of leisure activities. Identification with the ideal marks, in an opposing way, a dissociation from the negative attribute that the unemployed are linked to, that is, passivity. During the interviews, there are constant references to different types of activities, dealing with everything from job-seeking to leisure interests and comprising things that the respondents do as well as things that they plan to do. Camilla, who says that she wants to start up a company of her own, as well as hold lectures and write books, has a full schedule:

Daily routines: get the children to school, do the laundry, wash up, put stuff away, shop, eat lunch, go for a walk, fetch the children, make food. I attend a jiving course on Thursday evenings and I've done chi-gong, so I have that as something I do at home myself, I have it stored as a file on my phone. I can be anywhere and do it. That's how I carry on with one project and try to write a book. I've already written drafts for several.

Viktor attempts, despite doing full-time labor market work experience and being a parent, to find time to job seek, start up his own business, and pursue his leisure interests. Another interview is permeated by the respondent's plans and ambitions, for example, regular physical activity, travel, supplementing upper secondary school grades, and running a business. The internalizing of activity as an ideal also becomes clear in the stories of other unemployed people, where descriptions of adapting to the pace of long-term unemployment include a shift in the circadian rhythm. In line with the behaviors idealized within the discourse, the ability to be active and take responsibility, however, is emphasized by this respondent:

I find it very easy to be up late, I'm really very much a night-owl ... But then I find it quite easy to switch back once I get a steady job, kinda thing.

At the same time, this respondent describes how he becomes lazy during lengthy periods of unemployment. This retelling of the discourse can be interpreted as an internalizing of the attributes that the unemployed are linked to within this discourse. The internalizing of political ideals, and making them one's own, complies with the neo-liberal governance logic (Rose, 1999). The following respondent, too, feels that she has failed to live up to both society's and her own expectations:

I personally feel bad ... Because I haven't succeeded in finding a proper job.

Another example of how the discourse is internalized and leads to self-blame is illustrated by the metaphor that Andreas uses when describing how he feels: He considers himself 
to be a leech on society. Here, it becomes clear how power, which exists within individuals, causes them to steer themselves toward the kind of behavior that is expected within the discourse on the unemployed (Andersson, 2003), leading to a feeling of battening on society's resources. Thus, the internalizing of the discourse, and its negative connotation regarding the unemployed, may simultaneously imply stigmatization (Andersson, 2006). The unemployed display a recurrent awareness of the rooting of the discourse in society. Even though negative conceptions of the unemployed are not directly expressed, the respondents are thus aware of them and relate to them. This can become clear when being introduced to new acquaintances:

A failure. That might be what they're thinking then. You wonder what they're thinking about you now, when you don't have a job and so on. It has felt a bit that way to me, a bit like you know, hell it doesn't sound good kinda thing.

The internalizing and recreating of the discourse through conformity, with its ideals, is one way of relating to it. Other respondents, too, confirm the validity of the discourse, but stress at the same time the challenges they face when relating to it. Their standpoints are described in the following section.

\section{Distancing}

As we have seen, the individual's responsibility constitutes a key component of the stories of the unemployed and is something that they relate to. However, while the unemployed confirm the validity of the discourse, other parts of the social reality also exist, parts which, in relation to individualized responsibility, emerge as essential during the interviews (see Dahl, 2014). These other parts deal with the difficulties of living up to the ideals of the discourse, that is, the societal norm of earning one's keep, and make themselves felt during encounters with other people's expectations, reminding and making the unemployed conscious of breaking with norms and ideals.

The respondents problematized these aspects of the discourse, which became concrete in other people's expectations and comments, by positioning these other people. In doing so, the unemployed both adopted a stance on and showed where in the discourse they themselves were. This way of dealing with the discourse on the individual's responsibility not only underscores its validity but also questions it and underscores difficulties linked to it. This questioning results in a certain degree of dissociation from the discourse, or parts thereof. The expectations and comments that the respondents raise, thus questioning the ideal, primarily concern cultural norms and political opinions. Cultural and social patterns primarily regarded the nuclear family and bread-winner strategies. Isak says that his father thinks he is lazy and that he should start working. The norm is that

you have to get a job and earn your keep, and then you get a wife and have kids and live like Dylan's Mr Jones.

Isak adopts a stance on the societal norm that his father refers to and on his father's lack of understanding of his situation as unemployed by positioning them in an 'oldfashioned' system of values. Magnus relates to the discourse on the individualization of 
responsibility in a similar way when accounting for his elderly relatives' attitude toward his being unemployed:

Maybe it's more within my extended family, sort of. My grannie and that lot you know, they've said that kinda 'no job, well well well, the shame of it' like that kinda thing. That's the way it is in the older generations I guess, they've really had to toil for their daily bread, to put it like that.

Another way of adopting a stance on the difficulties of living up to the ideals of the discourse is to take up the significance of political opinions vis-à-vis how unemployment is viewed. In the following quote, the validity of the discourse is questioned through positioning toward a type of political opinion that shames the unemployed person for not living up to the ideal. Here, the respondent's observation tallies with research into the link between political orientation and how unemployment is viewed, such that leftoriented voters tend toward understanding the unemployed, while more conservative voters are inclined toward individualizing the blame for being unemployed (McFadyen, 1998; Fridberg \& Ploug, 2000):

People who make statements [like that] are those with right-wing views, they're the worst ones to bump into at a party, they're the ones that offend you the most. Because they're the ones that say 'you and your situation are self-inflicted.' That's something someone with left-wing views would never say, because they have different conception of the world.

The respondents thus start out from the correctness of the prevailing discourse, while simultaneously questioning it and, in doing so, dissociating themselves from parts of it. In the following section, there is a description of an approach characterized by resistance to the fundamental assumptions of the discourse with regard to the individual's shortcomings as an explanation of her or his unemployment.

\section{Resistance}

A third way of relating to the discourse involved questioning it more directly and resisting it. This resistance expressed itself when the respondents problematized the impossibility of getting a job, that is, factors they have no influence upon. The resistance also became clear in the respondents' stories about their encounters with others, when facing the image of unemployment as the result of an individual's deficiencies. Here, the unemployed emphasized assets that contradicted this image. The obstacles described are experiences on the labor market and the labor market situation in general. One example is the lack of social networks able to mediate contacts, as this impacts upon job opportunities that are not advertised, as well as being selected for an interview from among the recruiters' high stacks of applications:

I really had no contacts that could get me a job. All my mates work for their dads at their companies. But I really haven't had that kind of relationship with my relatives so I haven't been able to get a job that way.

Primarily, however, it is the high level of unemployment and financial restrictions faced by organizations and companies that are pointed out in the respondents' standpoints

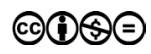


vis-à-vis the discourse. Fredrik, who trained as a mechanic with an HGV license during his initial period of unemployment in order to get a good job, laughs dejectedly when he says: 'But then, while I was there, the downturn came along.' Joakim worked as an hourly-waged and limited-duration employee for two years under the auspices of regional and municipal operations. Just before his two years were up, they stopped calling him in. It is reasonable to assume that this is related to the fact that he would otherwise have been entitled to permanent tenure under the Employment Protection Act (Swedish Code of Statutes, 1982:80).

The respondents' positioning is at its clearest, perhaps, in stories about encounters with people close at hand. Common to many of these encounters is the fact that they have led to the respondents feeling shame or humiliation, which seem to be the feelings having the greatest impact on people's self-image. These feelings arise when the unemployed have been noted for a personal deficiency, or for not living up to the expectations of those around them (Jönsson \& Starrin, 2000). By asserting a high level of education and great societal commitment, the following respondent resists the image of the unemployed as incompetent, uncommitted, and passive:

I feel well-informed, well-educated and so on. I keep tabs on things and get involved in issues that concern me or which I feel committed to.

On repeated occasions, discomfort is described in advance of impending social encounters, with relatives and friends as well as with new acquaintances, due to the unemployed person being reminded of how others see her or him and which expectations she or he is unable to live up to. This forces the respondent position her- or himself in relation both to the discourse and to the surroundings that recreate it (Andersson, 2006). Here, different strategies are used to resist and, in doing so, retain some dignity. One example is emphasizing a certain competence, even though this is not being practiced professionally:

Being out of work isn't really something that brings you great repute anywhere, so that's something you try to avoid saying and you find some other excuse instead. A mate of mine went to a wedding. As he didn't want to write that he was unemployed, he humorously wrote that he was an IT professional instead. Then he got out of saying what he didn't want to say: that he was out of work. Because then everyone started asking him what it's like being an IT professional, kind of thing.

Emphasizing knowledge of an area prized by society calls into question the norms that equate competence and waged-work. At the same time, this strategy can be interpreted as resistance to the conception of unemployment as being due to individual shortcomings, which is closely connected with the image of the unemployed as passive and lacking in competence.

\section{Summarizing discussion}

The purpose of the article is to shed light on how the discourse on the individualization of responsibility for unemployment is reflected in the stories of the unemployed, and to 
show how the young long-term unemployed position themselves in relation to this logic. It dominates the stories of the unemployed, which implies that it is not only a departure point in people's ways of thinking about unemployment but also that it is kept alive, that is, it is actively used (cf. Dahl, 2014). The validity of the discourse is prominent even though the unemployed relate to it in various ways. The analysis resulted in three overarching approaches; one way of relating to it is through conformity, suggesting that the discourse has been internalized and its ideals made one's own. Accounting for activity suggests an acceptance of, as well as homogeneity with, the ideals of the discourse. Similarly, self-blame confirms the fact that unemployment is linked to the individual's behaviors, attributes, and abilities.

Another way of adopting a stance on the dominant discourse is to question it by problematizing the difficulties of living up to its ideals with regard to doing one's bit, and the social norms connected with that. Here, the respondents adopt a stance on the discourse by positioning other people, whose opinions and comments have materialized the discourse. This type of standpoint is a dissociation from parts of the dominant discourse. The third way of relating to the discourse is through resistance to the fundamental assumptions of the discourse that unemployment is connected with individual shortcomings. The standpoint of the unemployed becomes clear during the problematization of the external circumstances that made their attempts to enter the labor market impossible. This resistance also appears when knowledge and abilities contradicting the image of unemployed people's assumed personal deficiencies are emphasized.

From these three overarching ways of relating to the discourse, two conclusions can be drawn. Firstly, these dissimilar ways of positioning demonstrate the importance of the discourse of individualized responsibility. This conclusion derives partly from the reoccuring common theme: regardless of how they relate to it, their starting point is the discourse on the individualization of responsibility. In part, the conclusion also stems from the fact that influences from predominating societal ideas such as the supranational discourse of the ideal worker and the concept if individualization can be traced in the reflections of unemployed regardless of their approaches to the discourse of individualized responsibility.

References to the discourse of the ideal worker are traceable in the two standpoints that are the most dissimilar: the conform unemployed underlined their high level of activity, and the resisting unemployed highlighted competencies, experiences, and skills. Both of these sorts of traits are comprised in supranational discourses about unemployment and welfare, where employability, flexibility, and autonomy characterize the notion of the active entrepreneur adapting to the dynamic, changing economies as part of the 'active society' (Crespo \& Serrano Pascual, 2007).

Individualization, in turn, is a term with many connotations that can be understood from several perspectives. When it comes to the understanding that I have started out from in the present article, that is, the individual-focused responsibility for unemployment linked to an image of unemployment being due to the individual's deficiencies, it may entail implications for people in vulnerable positions. One such group is long-term unemployed young adults. For many of those in this age group, unemployment is close to normalized, something that is linked to the constant and relatively high level of unemployment that has been characterizing the labor market since the 1990s. At the same time, they are surrounded by a social climate wherein the prevailing discourse mediates an image of unemployment as something caused by personal shortcomings. Further, they

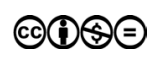


are surrounded by an understanding of individualization as a source of possibilities and opportunities waiting to be realized. For those young unemployed who have the same understandings and expectations, the labor market policies emphasizing individualization and individualized measures seem positive. However, for those who do not share these views, individualization may entail asymmetric power relations with implications for the acknowledgement of the individual's views and needs (see Ulmestig, 2013). Thus, the concept of individualization may entail very different results for different groups, for instance not only according to the individual's own views but also according to social class (Gillberg, 2010). This differentiation is beyond the scope of the present study, but forms an interesting task for future research.

The second conclusion concerns the value of social relations with family, friends, or acquaintances in relation to different aspects of unemployment. One aspect is related to the labor market. The role the young unemployed ascribe to contacts in order to get a job repeatedly appears in the interviews, as in scholarly writings (e.g., Granovetter, 1973, 1983; Gush et al., 2015; Marek et al., 2015). Another aspect considers well-being. The link between well-being and social networks has led to inconclusive results. Some studies demonstrate a positive impact of supportive social relations (Clark \& Clissold, 1982; Hendry et al., 1984), while others have shown that social support may have ambivalent or even negative effects, in particular among young adults (Hendry \& Raymond, 1986; Hammer 1993, 2000). In the present study, both tendencies underlie the reflections of the unemployed. On the one hand, some unemployed portrayed a close to normalized understanding of unemployment among peers, which possibly mitigated the negative impact of unemployed-related distress (see Clark \& Oswald, 1994). Conversely, given the recurrent shaming and degrading experiences, many unemployed have faced from family members, friends, and acquaintances because of their joblessness, the social surroundings may clearly also have negative effects. This evidence indicates that the quality of the social relations may have a very different effect on the self-esteem, well-being, and social identity of the unemployed. Thus, the interrelation between the well-being among unemployed on the one hand and the amount and sources of social support, its qualities, and its outcomes on the other hand clearly would benefit from more scholarly attention.

Nevertheless, undoubtedly, shaming and degrading experiences, which are often discussed in terms of stigmatizing experiences, may have a detrimental impact on the individual's well-being and mental health (Starrin et al., 1996). The stigma can be reinforced via labor market and sociopolitical strategies that build on an all too narrow interpretation of the individual's responsibilities. In cases where these policies do not separate the individual's choices from the prerequisites and circumstances impacting upon her or his choices, that is, the social structures underlying many behaviors, societal inequalities run the risk of becoming reinforced. In other words, there is a risk that individuals who are in an already vulnerable and exposed position are blamed, while underlying social injustices remain untouched (Cantillon \& Van Lancker, 2013).

Hence, one strategy for enabling the unemployed to make use of the opportunities on offer could be through consideration to be paid not just to the individual's strengths and competencies but also to her or his prerequisites and everyday life (see Van Berkel \& Valkenburg, 2007). This includes knowledge of how the unemployed deal with the discourse on individualized responsibility. This study makes a contribution to this understanding. At the same time, the findings pose questions that require further research, both with regard to conceptions of unemployment and the strategies for dealing with 
them. More empirical studies are needed of how this individualization of responsibility, as well as the strategies for positioning oneself in accordance with it, affect the mental well-being of the unemployed, and their opportunities on the labor market. In a more long-term perspective, questions also arise regarding how individualized responsibility influences societal structures such as social citizenship and social trust.

\section{Acknowledgments}

This article is based on data collected within the project entitled 'Youth, Unemployment, and Exclusion in Europe: A Multidimensional Approach to Understanding the Conditions and Prospects for Social and Political Integration of Young Unemployed' (YOUNEX), financed by the European Commission and the $7^{\text {th }}$ framework programme (ref. no. 216122).

\section{References}

Agell, J., Lundborg, P. (1999) 'Survey evidence on wage rigidity and unemployment: Sweden in the 1990s', Working paper 1999: 2. Uppsala: Institute for Evaluation of Labor Market and Education Policy.

Allvin, M., Aronsson, G., Hagström, T., Johansson, G., Lundberg, U. (2011) Work without boundaries. Psychological perspectives on the new working life. Oxford: Wiley-Blackwell.

Andersson, M. (2003) Arbetslöshet och arbetsfrihet: moral, makt och motstånd. [Unemployment and freedom of employment: morality, power and resistance.] PhD thesis. Uppsala: Uppsala University.

Andersson, M. (2006) 'Att känna sig arbetslös - kategori, identifikation och stigmatisering' [Feeling unemployed - category, identification and stigmatization], in: Mäkitalo, Å. (ed): Att hantera arbetslöshet. Om social kategorisering och identitetsformning $i$ det senmoderna [Coping with unemployment. On social categorization and identity shaping in late modernity] (pp. 67-92). Arbetsliv I Omvandling no. 16.

Beck, U. (2000) Risksambället. På väg mot en annan modernitet. Göteborg: Daidalos.

Bengtsson, M., Berglund, T. (2012) 'Den stora omvandlingen - svensk arbetsmarknadspolitik under tre decennier' [The great transformation - Swedish labour market policy during three decades], Arbetsmarknad och Arbetsliv 18(3): 21-33.

Berger, P., Luckmann, T. (1967) The social construction of reality: A treatise in the sociology of knowledge. New York: Anchor Books.

Calmfors, L., Forslund, A., Hemström, M. (2001) 'Does active labor market policy work? Lessons from the Swedish experiences', Swedish Economic Policy Review 85: 61-124.

Cantillon, B., Van Lancker, W. (2013) 'Three shortcomings of the social investment perspective', Social Policy and Society 12(4): 55-564.

Clark, A. E., Oswald, A. J. (1994) 'Unhappiness and unemployment', The Economic Journal, 104: 648-659. doi: http://dx.doi.org/10.2307/2234639.

Clark, A. W., Clissold, M. P. (1982) 'Correlates of adaptation among unemployed and employed young men', Psychological Reports, 50: 887-893. doi: http://dx.doi.org/10.2466/ pr0.1982.50.3.887.

Crespo, E., Serrano Pascual, A. (2004) 'The EU's concept of activation for young people: towards a new social contract?', in: Serrano Pascual, A. (ed): Are activation policies converging in Europe? Brussels: ETUI. 
Crespo, E., Serrano Pascual, A. (2007) 'Political production of individualized subjects in the paradoxical discourse of the EU institutions, in: Van Berkel, R.,Valkenburg, B. (eds) Making it Personal. Individualising Activation Services in the EU (pp. 107-126). Policy Press, Bristol.

Dahl, E. (2014) Om miljöproblemen hänger på mig. Individer förhandlar sitt ansvar för miljön. [If the environmental problems are up to me. Individuals negotiate their responsibility for the environment.] $\mathrm{PhD}$ thesis. Gothenburg: Makadam förlag.

Davies, B., Harré, R. (1990) 'Positioning: The discursive production of selves', Journal for the theory of social behaviour, 20(1): 43-63. doi: http://dx.doi.org/10.1111/j.1468-5914.1990. tb00174.x.

Eardley, T., Matheson, G. (2000) 'Australian Attitudes to Unemployment and Unemployed People', Australian Journal of Social Issues, 35(3): 181-202.

Fridberg, T., Ploug, N. (2000) 'Public attitudes to unemployment in different European welfare regimes', in Gallie, D., Paugam, S. (eds): Welfare regimes and the experience of unemployment in Europe (pp. 334-348). Oxford University Press.

Furlong, A. (ed.) (2009) Handbook of Youth and Young Adulthood. New perspectives and agendas. London: Routledge.

Furnham, A. (1982) 'The Protestant work ethic and attitudes towards unemployment', Journal of Occupational Psychology, 55(4): 277-285. doi: http://dx.doi.org/10.1111/ j.2044-8325.1982.tb00101.x.

Furåker, B., Blomsterberg, M. (2002) 'Attitudes towards the unemployed. An analysis of Swedish survey data', International Journal of Social Welfare, 12: 193-203. doi: http://dx. doi.org/10.1111/1468-2397.t01-1-00005.

Gallie, D. (1994) 'Are the unemployed an under-class? Some evidence from the social change and economical life initiative', Sociology, 28(2): 737-757. doi: http://dx.doi.org/10.1177/ 0038038594028003006.

Gallie, D., Paugam, S. (2002) Social precarity and social integration. Brussels: European Commission.

Giddens, A. (2003) Sociologi, 3rd ed. Lund: Studentlitteratur.

Gillberg, G. (2010) Individualiseringens villkor. Unga vuxnas föreställningar om arbete och självförverkligande. [Conditions of individualization. Young adults' conceptions of work and self-realization] Doctoral dissertation. Gothenburg: Gothenburg university.

Glaser, B. G., Strauss, A. L. (1967) The discovery of Grounded Theory: Strategies for qualitative research. Chicago: Aldine.

Granovetter, M. S. (1973) 'The Strength of Weak Ties', American Journal of Sociology, 78(6): 1360-1380. doi: http://dx.doi.org/10.1086/225469.

Granovetter, M. S. (1983) 'The Strength of Weak Ties: A Network Theory Revisited', Sociological Theory, 1: 201-233. doi: http://dx.doi.org/10.2307/202051.

Grimmer, B., Hobbins, J. (2014) 'Active entrepreneurs and blue-collar workers. Cultural understandings mirrored in European youth unemployment policies', International Journal of Sociology and Social Policy, 34(7/8): 559-576. doi: http://dx.doi.org/10.1108/ IJSSP-07-2013-0084.

Gush, K., Scott, J., Laurie, H. (2015) Job loss and social capital: The role of family, friends and wider support networks. ISER Working Papers Series No 2015-07. Essex: Institute for Social and Economic Research.

Hammer, T. (2000) 'Mental health and social exclusion among unemployed youth in Scandinavia: a comparative study', International Journal of Social Welfare, 9: 53-63. doi: http://dx.doi.org/10.1111/1468-2397.00108.

Hammer, T. (1993) 'Unemployment and mental health among young people: a longitudinal study', Journal of Adolescence, 16: 407-420. doi: http://dx.doi.org/10.1006/jado.1993.1033. 
Handler, J. F. (2003) 'Social citizenship and workfare in the US and Western Europe: From status to contract', Journal of European Social Policy, 13(3): 229-243. doi: http://dx.doi. org/10.1177/09589287030133002.

Hendry, L. B., Raymond, M. J., Stewart, C. (1984) 'Unemployment, school and leisure: an adolescent study', Leisure Studies, 3: 175-187. doi: http://dx.doi.org/10.1080/ 02614368400390151.

Hendry, L. B., Raymond, M. J. (1986) 'Psycho-social aspects of youth unemployment: an interpretative model', Journal of Adolescence, 9: 355-366. doi: http://dx.doi.org/10.1016/ S0140-1971(86)80041-0.

Johansson, H., Møller, I. H. (2009) 'Vad menar vi med aktivering?' [What do we mean by activation?], in Johansson, H., Møller, I. H. (eds): Aktivering - arbetsmarknadspolitik och socialt arbete $i$ förändring [Activation - the transformation of labour market policy and social work] (pp. 9-30). Malmö: Liber.

Junestav, M. (2004) Arbetslinjer i svensk socialpolitisk debatt och lagstiftning 1930-2001. [Work strategies in Swedish social policy debates and legislation] PhD thesis. Uppsala: Uppsala University.

Junestav, M. (2009) 'Språkbruk och institutionell förändring' [Language and institutional change], Arbetsmarknad och Arbetsliv, 15(4): 9-27.

Jönsson, L. R., Starrin, B. (2000) 'Ekonomi-skam modellen och reaktioner på arbetslöshet' [The finances-shame model and reactions to unemployment], Socialvetenskaplig tidskrift, 3: 267-284.

Marek, P., Damm, B., Su, T.-Y. (2015) 'Beyond the Employment Agency:The Effect of Social Capital on the Duration of Unemployment'. SOEP Papers on Multidisciplinary Panel Data Research DIW Berlin.

McFadyen, R. G. (1998) 'Attitudes toward the unemployed', Human Relations, 51(2): 157-177. doi: http://dx.doi.org/10.1023/A:1016914319477.

Mead, L. (1986) Beyond entitlement - the social obligations of citizenship. New York: Anchor Press.

Miles, M. B., Huberman, A. M. (1994) Qualitative data analysis: an expanded sourcebook. 2. ed. Thousand Oaks, CA: Sage.

Morel, N., Palier, B., Palme, J. (2012) ‘Beyond the welfare state as we knew it?’, in: Morel, N., Palier, B., Palme, J. (eds) Towards a social investment welfare state? Ideas, policies and challenges (pp. 1-32). Bristol: Policy Press.

Nordström Skans, O., Kramarz, F. (2011) 'Sociala kontakter och ungdomars inträde på arbetsmarknaden' [Social contacts and young peoples' entrance into the labour market], Report 2011:21. Uppsala: Institute for Evaluation of Labor Market and Education Policy.

Oschmiansky, F. (2003) 'Faule Arbeitslose? Zur Debatte über Arbeitsunwillingkeit und Leistungsmissbrauch' [Lazy unemployed? On the debate about unwillingness to work and misuse of entitlements], Aus Politik und Zeitgeschichte, 6-7: 10-16.

Ostrom, E. (2005) Understanding institutional diversity. Princeton: Princeton University Press.

Government Bill (2010/11:1) Budget proposal for 2011. Expenditure zone 14: Labor market and working life. Stockholm: Ministry of Finance.

Rantakeisu U (2002) Arbetslöshetens olika ansikten. Fyra studier om arbetslöshetens sociala och hälsomässiga yttringar [The different faces of unemployment. Four studies on the social and health-related . PhD thesis. Göteborg: Göteborgs universitet.

Rose, N. (1999) Powers of freedom. Cambridge: Cambridge University Press.

Salonen, T. (2009) 'Aktivering i socialt arbete. Dåtid och nutid' [Activation in social work, formerly and today], in: Johansson, H., Möller, I. H. (eds): Aktivering [Activation] (pp. 55-86). Malmö: Liber. 
Sennett, R. (2000) När karaktären krackelerar: Människan i den nya ekonomin. [The corrosion of character. The Personal Consequences of Work in the New Capitalism] Stockholm: Atlas.

Swedish Federation of Unemployment Insurance Funds (2008) Historik över arbetslöshetsförsäkringen från 1885 framåt. [Historical overview of the unemployment insurance from 1885 onwards] Stockholm: Swedish Federation of Unemployment Insurance Funds.

Starrin, B., Forsberg, E., Rantakeisu, U. (1999) 'I arbetslöshetens spår - ekonomisk stress, skam och ohälsa' [In the aftermath of unemployment - financial distress, shame and illhealth], in: Härenstam, A., Lundberg, U., Lindbladh, E., Starrin, B. (eds): I vanmaktens spår [In the aftermath of powerlessness] (pp. 21-93). Umeå: Boréa.

Starrin, B., Rantakeisu, U., Hagqvist, C. (1996) ‘Om arbetslöshetens ekonomi och skam’ [On the finances and shame of unemployment], Socialvetenskaplig tidskrift, 1-2: 91-115.

Svallfors, S. (2011) 'A bedrock of support? Trends in welfare state attitudes in Sweden, 19812010', Social Policy and Administration, 45(7): 806-825. doi: http://dx.doi.org/10.1111/ j.1467-9515.2011.00796.x.

Ulmestig, R. (2013) 'Individualisering och arbetslösa ungdomar' [Individualization and unemployed youth], Arbetsmarknad och arbetsliv, 19(3): 25-38.

Valkenburg, B. (2007) 'Individualising activation policies: thrashing out an ambiguous concept', in: Van Berkel, R., Valkenburg, B. (eds): Making it personal: individualising activation services in the EU (pp. 25-44). Bristol: Policy.

Van Oorschot, W. (2006) 'Making the difference in social Europe: deservingness perceptions among citizens of European welfare states', Journal of European Social Policy, 16(1): 23-42. doi: http://dx.doi.org/10.1177/0958928706059829.

Willis, P. (1986) 'Unemployment: the final inequality', British Journal of Sociology and Education, 7(2): 155-169. doi: http://dx.doi.org/10.1080/0142569860070204.

Winter Jørgensen, M., Phillips, L. (2000) Diskursanalys som teori och metod. Lund: Studentlitteratur. 